\title{
Da Educação, das Artes e do pensamento
}

A edição da Revista Dialogia no. 28, Educação e Artes, apresenta um recorte que se pretende atualizado para mostrar, uma vez mais, a importância das Artes para a Educação em todos os níveis e graus. Não se trata, de forma alguma, de encarar as Artes, em suas diversas linguagens, como simples estratégias de aprendizagem ou, pior ainda, de pensar nas linguagens artísticas como meras ferramentas auxiliares para modelos educacionais já propostos e, muitas vezes, ultrapassados.

Os grandes pensadores e, também, educadores tais como: Bergson, Sartre, Deleuze, Simone de Beauvoir, Bachelard, Foucault, Merleau-Ponty, Ricoeur, Paulo Freire, Haroldo de Campos, Stephen Hawking e tantos outros que poderíamos enumerar, há dezenas e dezenas de anos sempre souberam que as Artes, certamente incluindo a Literatura, tiveram um papel fundamental para o exercício do pensamento e, fundamentalmente, para a criação de teorias renovadoras. Transgressoras.

Os verdadeiros expoentes da humanidade e da Educação sempre souberam que as Artes não são meras atividades de deleite ou entretenimento. Mas sempre pensaram as Artes enquanto produtoras de conceitos e problematizações importantes, por diversos momentos, quase insondáveis, no que tange à intuição (de forma fundamentada), assim como seu papel na questão da estética, naturalmente, incluindo a Educação. Não se deve esquecer que as Artes sempre caminham à frente. Ulteriormente, a lógica (seja ela qual for) com teorias e possíveis metodologias. Em especial, aquelas que não petrificam a arte do pensamento. Nunca é demais lembrar: a gramática acontece depois de Homero. A teoria do romance depois do romance. As partituras surgem depois das canções e assim por diante.

Nessa medida, o nosso entrevistado deste número é o Prof. Dr. Juliano Casimiro de Camargo Sampaio da Universidade do Tocantins (UFT). Na entrevista fala, entre tantas outras coisas, de seu percurso profissional e de quanto a Arte Teatral foi fundamental em sua vida. Desde a infância. Fala-nos, inclusive, de suas experiências felizes envolvendo, prioritariamente, a linguagem teatral e a Educação. 
Integrando o dossiê, o artigo da Dra. Lucia Santaella e Clayton Policarpo discute a confluência das linguagens que nos permeiam. O quanto o surgimento de novas linguagens interfere em nossa percepção. Os autores nos oferecem uma análise aguda sobre o impacto das diversas tecnologias de comunicação em relação, principalmente, às questões que envolvem a leitura e os receptores. Procuram definir o leitor imersivo, o leitor ubíquo e o papel da estética do conhecimento.

No artigo da Dra. Catarina Justus Fischer há uma importante elaboração, reflexiva, a respeito da linguagem musical. A autora propõe, a partir, em especial, de suas experiências na área da Educação, algumas alternativas que poderão ser um poderoso instrumento no que tange ao pensamento e, ao mesmo tempo, refletir a música sob perspectivas de uma abertura para a estética e para a sensibilidade. Lembra o quanto a música é uma linguagem poderosa, se pensarmos em questões que envolvem multiplicidade e simultaneidade.

O artigo do Prof. Dr. Celso do Prado Ferraz de Carvalho e Maurício Braz de Carvalho faz uma investigação a respeito do retorno do Ensino Musical à Educação Básica do Brasil. Nessa perspectiva, os autores analisam a importância da linguagem da música no processo de construção social da escola pública brasileira.

O texto Folhetos de cordel no ensino de lingua materna: A aula de leitura revisitada, do Prof. Dr. Linduarte Pereira Rodrigues faz uma análise da literatura de cordel no que tange métodos e práticas para as aulas de língua portuguesa.

Posteriormente, os artigos que acompanham o dossiê trazem contribuições significativas para que se possa pensar não somente metodologias e modelos aplicados à Educação, mas, inclusive, espaços de muita reflexão sobre as práticas e experiências docentes que não indicam, apenas, modelos e receitas. Indicam o quanto a criatividade e sensibilidade devem integrar o percurso docente.

As resenhas publicadas neste número são verdadeiros convites de leitura. Instigantes. Provocativas. Apontam, mais do que nunca, a necessidade de acompanharmos as publicações mais recentes. Não somente leituras específicas da área. A Educação, acima de qualquer coisa, deve dialogar com diferentes instâncias do conhecimento. Diante disso, as duas resenhas apresentam obras que vão além do conteúdo delas mesmas. Demonstram claramente que a literariedade (dos livros resenhados) é o ponto fundamental de obras ensaísticas. Revelam um estilo singular e aberto. Ou seja, a forma, o ritmo, o deslocamento da pontuação 
e, consequentemente, da sintaxe. Demonstram que nada vale um conteúdo sem aquilo que definitivamente singulariza a autoria, que, por sua vez, define a tão sonhada autonomia intelectual. Com isso quem ganha são os leitores. Acabam por compreender a importância de forma e conteúdo enquanto conceitos inseparáveis. Necessários.

Desejamos a todos uma boa leitura!

As editoras

Ana Maria Haddad Baptista

Márcia Fusaro 
